\title{
SPHAERODORIDS (POLYCHAETA, SPHAERODORIDAE) FROM THE CONTINENTAL MARGIN OFF THE NW IBERIAN PENINSULA, WITH FIRST RECORD OF SPHAERODOROPSIS SIBUETAE AND $S$. AMOUREUXI SINCE THE ORIGINAL DESCRIPTION
}

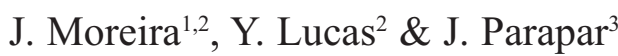

\begin{abstract}
J. Moreira, Y. Lucas \& J. Parapar. 2011. Sphaerodorids (Polychaeta, Sphaerodoridae) from the continental margin off NW Iberian Peninsula, with first record of Sphaerodoropsis sibuetae and S. amoureuxi since original description. Grael/sia, 67(1): 23-33.

Knowledge of the Sphaerodoridae (Annelida, Polychaeta) is still scarce in many parts of the world, including deep-sea waters around the Iberian Peninsula. Study of samples collected between 100-2000 m depth during several oceanographic expeditions done at the Galician Continental Margin (NW Iberian Peninsula) from 2003 to 2009 revealed the presence of six species of sphaerodorid polychaetes. Two species are reported for the first time since the original description, namely Sphaerodoropsis sibuetae Desbruyères, 1980 and $S$. amoureuxi Aguirrezabalaga \& Ceberio, 2005; these records extend the known distribution of these species to the West of the Atlantic Ocean. All species collected are reported including distribution and ecological data as well as a key to all species known from the lberian Peninsula.
\end{abstract}

Key words: Iberian Peninsula; Polychaeta; Sphaerodoridae; Sphaerodoropsis sibuetae; Sphaerodoropsis amoureuxi; distribution.

\section{RESUMEN}

J. Moreira, Y. Lucas \& J. Parapar. 2011. Esferodóridos (Polychaeta, Sphaerodoridae) del margen continental del NW de la península lbérica y primer registro de Sphaerodoropsis sibuetae y S. amoureuxi tras su descripción original. Grael/sia, 67(1): 23-33 (en inglés).

El conocimiento sobre los Sphaerodoridae (Annelida, Polychaeta) es todavía insuficiente en muchas partes del planeta, incluyendo los fondos del sistema marino profundo de la península lbérica. El estudio de las muestras recogidas entre 100 y 2000 m de profundidad durante varias campañas oceanográficas en el Margen Continental de Galicia (NW península lbérica) entre 2003 y 2009 ha mostrado la presencia de seis especies de poliquetos pertenecientes a la familia Sphaerodoridae. Dos de estas especies son mencionadas por primera vez desde su descripción original: Sphaerodoropsis sibuetae Desbruyères, 1980 y S. amoureuxi Aguirrezabalaga \& Ceberio, 2005; estos registros extienden la distribución

\footnotetext{
Departamento de Biología (Zoología), Universidad Autónoma de Madrid, Cantoblanco, E-28049 Madrid, Spain. E-mail: juan.moreira@uam.es

2 Estación de Bioloxía Mariña da Graña, Universidade de Santiago de Compostela, Rúa da Ribeira 1, A Graña, E-15590 Ferrol, Spain.

3 Departamento de Bioloxía Animal, Bioloxía Vexetal e Ecoloxía, Facultade de Ciencias, Universidade da Coruña, Alejandro de la Sota 1, E-15008 A Coruña, Spain.
} 
conocida de ambas especies hacia el Oeste en el Océano Atlántico. Asimismo, se mencionan todas las especies encontradas aportando datos sobre su distribución y ecología, y se incluye una clave con todas las especies conocidas de la península lbérica.

Palabras clave: Península Ibérica; Polychaeta; Sphaerodoridae; Sphaerodoropsis sibuetae; Sphaerodoropsis amoureuxi; distribución.

\section{Introduction}

Sphaerodorids (Polychaeta, Sphaerodoridae) are small-sized polychaetes mostly distinguishable by having tubercles and papillae on the dorsum, sometimes arranged in a definite, non-random pattern (Fauchald, 1974). Systematics of the Sphaerodoridae have traditionally been confusing and problematic (Lützen, 1961; Fauchald, 1974) and their position within the Phyllodocida has not been resolved yet (Aguado \& Rouse, 2006). In addition, there is a need for a full revision of the taxonomic status of the genera, mostly Sphaerodoropsis Hartman \& Fauchald, 1971 (Borowski, 1994; Aguado \& Rouse, 2006). Indeed, descriptions of many species are inaccurate and brief, not giving much relevant information of characters such as the distribution of body papillae and the shape of the proventricle or whether there are special structures on the parapodia and spinulation on chaetae (but see, for example, Kudenov, 1987b; Moreira et al., 2004; Aguado \& Rouse, 2006; Böggemann, 2009; Reuscher \& Fiege, 2011). On the other hand, the taxonomy, distribution, biology and ecology of sphaerodorids are still poorly known in many geographic areas; this is related, in part, to the fact that they can easily be overlooked due to their small size when using mesh of coarse size or during the processing of samples (Borowski, 1994). Recent papers have, however, shown that sphaerodorids can be collected in numbers in soft bottoms when using sampling gear such as the Epibenthic Sledge of Brenke (2005) or the Macer-GIROQ Epibenthic Sledge (see Moreira \& Parapar, 2007, 2011; Schüller \& Ebbe, 2007; Böggemann, 2009; Reuscher \& Fiege, 2011).

To date, five sphaerodorid genera have been reported from the Iberian Peninsula, comprising ten species in total (Campoy, 1982; Sardá, 1983, 1987; Aguirrezabalaga \& Ceberio, 2005; Moreira et al., 2004; Moreira \& Parapar, 2007). In general, many records of sphaerodorids around the Iberian Peninsula come from intertidal or shallow-water areas. In the last years, examination of samples from the continental shelf and deep-sea areas have revealed the presence of several new taxa and provided new records as well (Aguirrezabalaga \& Ceberio, 2005; Moreira \& Parapar, 2007). Thus, Aguirrezabalaga \& Ceberio (2005) describe two new species of Sphaerodoropsis from the Capbreton Canyon and provide the first record of Sphaerodoridium fauchaldi Hartmann-Schröder, 1993 since the original description. Later, Moreira \& Parapar (2007) report again $S$. fauchaldi from the continental shelf off Galicia and further describe a new species of Sphaerodoropsis, both collected during the DIVA-Artabria I 2002 expedition.

Examination of further sphaerodorid material collected during 2003, 2004, 2008 and 2009 cruises along the Galician coast (projects DIVA-Artabria $I$ \& II and Vertidos 2004), at depths between 100$2000 \mathrm{~m}$, has revealed the presence of six sphaerodorid species. These include two species of Sphaerodoropsis which had not been reported after their original description, namely Sphaerodoropsis sibuetae Desbruyères, 1980 and S. amoureuxi Aguirrezabalaga \& Ceberio, 2005. In this paper, specimens of the two aforementioned taxa are described and figured and a full list of all sphaerodorids collected is provided, also including the available ecological data.

\section{Material and Methods}

The material examined was obtained during the following expeditions: DIVA-Artabria I 2003 (September 2003), Vertidos 2004 (September 2004), DIVA-Artabria II 2008 (September 2008) and DIVA-Artabria II 2009 (October 2009), conducted along the western Galician Continental Margin, from the Ártabro Gulf in the North to off the Ria de Vigo in the South. Benthic samples were taken at depths of 100-2000 m (Table 1). A total of 498 sphaerodorid specimens were collected, mostly by means of an Epibenthic Sledge (EBS; Brenke, 2005); additional specimens were obtained by means of a Naturalist Dredge (DRN). Sampling methodology with both sampling gears and pro- 
Table 1.- Coordinates, date, depth and nature of substratum of sampling stations where Sphaerodoridae were collected in the expeditions DIVA-Artabria / 2003, Vertidos 2004, DIVA-Artabria // 2008 and 2009. Number of individuals (N) and species of Sphaerodoridae found in each sample are also indicated. EBS, Epibenthic sledge; DRN, Naturalist dredge.

Tabla 1.- Coordenadas, fecha, profundidad y naturaleza del sustrato de las estaciones de muestreo donde fueron recolectados Sphaerodoridae en las campañas DIVA-Artabria / 2003, Vertidos 2004, DIVA-Artabria // 2008 y 2009. Se indica el número de individuos $(\mathrm{N})$ y especies de Sphaerodoridae encontrados en cada muestra. EBS, Trineo epibentónico; DRN, draga de naturalista.

\begin{tabular}{|c|c|c|c|c|c|c|c|c|}
\hline Expedition & Station & Sampling date & Depth (m) & Latitude (N) & Longitude (W) & Substratum & $\mathrm{N}$ & Species \\
\hline DIVA I 03 & EBS-100 & $11 / 09 / 03$ & $102-103$ & $43^{\circ} 26^{\prime} 42^{\prime \prime}$ & $008^{\circ} 30^{\prime} 40^{\prime \prime}$ & Muddy sand & 15 & $\begin{array}{l}\text { S. fauchaldi, } \\
\text { S. amoureuxi }\end{array}$ \\
\hline DIVA I 03 & EBS-150 & $14 / 09 / 03$ & $149-152$ & $43^{\circ} 34^{\prime} 07^{\prime \prime}$ & $008^{\circ} 36^{\prime} 33^{\prime \prime}$ & Muddy sand & 151 & $\begin{array}{l}\text { S. fauchaldi, } \\
\text { S. artabrensis }\end{array}$ \\
\hline DIVA I 03 & EBS-200 & $12 / 09 / 03$ & $197-207$ & $43^{\circ} 40^{\prime} 15^{\prime \prime}$ & $008^{\circ} 43^{\prime} 45^{\prime \prime}$ & Muddy sand & 42 & $\begin{array}{l}\text { S. fauchaldi, } \\
\text { S. artabrensis }\end{array}$ \\
\hline DIVA I 03 & EBS-600 & $18 / 09 / 03$ & $598-610$ & $43^{\circ} 48^{\prime} 35^{\prime \prime}$ & $008^{\circ} 51^{\prime} 24^{\prime \prime}$ & Sand and stones & 5 & S. gracile \\
\hline DIVA I 03 & DRN-600 & $18 / 09 / 03$ & $599-607$ & $43^{\circ} 48^{\prime} 25^{\prime \prime}$ & $008^{\circ} 51^{\prime} 27^{\prime \prime}$ & Stones with corals & 4 & S. gracile \\
\hline Vertidos 04 & GA-EBS-150 & $25 / 09 / 04$ & 151 & $43^{\circ} 31^{\prime} 58^{\prime \prime}$ & $008^{\circ} 37^{\prime} 40^{\prime \prime}$ & Muddy sand & 12 & $\begin{array}{l}\text { S. fauchaldi, } \\
\text { S. artabrensis }\end{array}$ \\
\hline Vertidos 04 & GA-EBS-200 & $26 / 09 / 04$ & 201 & $43^{\circ} 36^{\prime} 19^{\prime \prime}$ & $008^{\circ} 52^{\prime} 51^{\prime \prime}$ & Sand & 2 & $\begin{array}{l}\text { S. fauchaldi, } \\
\text { S. amoureuxi }\end{array}$ \\
\hline Vertidos 04 & GA-EBS-600 & $28 / 09 / 04$ & $601-619$ & $43^{\circ} 36^{\prime} 32^{\prime \prime}$ & $009^{\circ} 03^{\prime} 04^{\prime \prime}$ & Sand & 1 & S. gracile \\
\hline Vertidos 04 & CA-EBS-150 & $18 / 09 / 04$ & $148-151$ & $42^{\circ} 50^{\prime} 30^{\prime \prime}$ & $009^{\circ} 25^{\prime} 46^{\prime \prime}$ & Muddy sand & 45 & $\begin{array}{l}\text { S. fauchaldi, } \\
\text { S. artabrensis }\end{array}$ \\
\hline Vertidos 04 & AG-EBS-150 & $17 / 09 / 04$ & 158 & $42^{\circ} 30^{\prime} 23^{\prime \prime}$ & $009^{\circ} 19^{\prime} 31^{\prime \prime}$ & Muddy sand & 121 & $\begin{array}{l}\text { S. fauchaldi, } \\
\text { S. artabrensis }\end{array}$ \\
\hline Vertidos 04 & AG-EBS-250 & $19 / 09 / 04$ & $242-248$ & $42^{\circ} 31^{\prime} 10^{\prime \prime}$ & $009^{\circ} 23^{\prime} 23^{\prime \prime}$ & Muddy sand & 8 & $\begin{array}{l}\text { S. fauchaldi, } \\
\text { S. artabrensis }\end{array}$ \\
\hline Vertidos 04 & CH-EBS-150 & $21 / 09 / 04$ & $149-150$ & $42^{\circ} 15^{\prime} 47^{\prime \prime}$ & $009^{\circ} 10^{\prime} 30^{\prime \prime}$ & Fine sand & 6 & S. artabrensis \\
\hline DIVA II 08 & DRN-30 & $29 / 09 / 08$ & $1974-2034$ & $42^{\circ} 31^{\prime} 66^{\prime \prime}$ & $009^{\circ} 40^{\prime} 00^{\prime \prime}$ & Mud & 1 & S. sibuetae \\
\hline DIVA II 09 & EBS-93 & $23 / 10 / 09$ & $264-265$ & $42^{\circ} 20^{\prime} 31^{\prime \prime}$ & $009^{\circ} 22^{\prime} 40^{\prime \prime}$ & Muddy sand & 1 & S. fauchaldi \\
\hline DIVA II 09 & EBS-94 & 23/10/09 & $260-264$ & $42^{\circ} 15^{\prime} 49^{\prime \prime}$ & $009^{\circ} 22^{\prime} 41^{\prime \prime}$ & Fine sand & 56 & $\begin{array}{l}\text { S. gracile, } \\
\text { S. fauchaldi, } \\
\text { S. amoureuxi, } \\
\text { S. artabrensis }\end{array}$ \\
\hline DIVA II 09 & EBS-95 & 24/10/09 & $258-275$ & $42^{\circ} 10^{\prime} 42^{\prime \prime}$ & $009^{\circ} 22^{\prime} 37^{\prime \prime}$ & Mud & 27 & S. fauchaldi \\
\hline DIVA II 09 & EBS-96 & $24 / 10 / 09$ & $302-330$ & $42^{\circ} 05^{\prime} 35^{\prime \prime}$ & $009^{\circ} 22^{\prime} 49^{\prime \prime}$ & Fine sand & 1 & E. abyssorum \\
\hline
\end{tabular}

cessing of samples is described in detail in Parapar \& Moreira (2009).

Observations, drawings and measurements of specimens were made using an Olympus BX40 compound microscope connected to a drawing tube. Selected specimens were deposited at the Museo Nacional de Ciencias Naturales (MNCN), Madrid, Spain. The nomenclature of prostomial appendages follows that of Aguirrezabalaga \& Ceberio (2005). The abbreviations for the structures referred in the figures are the following: ap, dorsal antenniform papilla; dpa, dorsal parapodial papilla; ia, intermediate lateral antenna; lpa, lateral parapodial papilla; ma, median antenna; pa, palps; pc, peristomial cir- rus; prl, prechaetal lobe; psl, postchaetal lobe; vpa, ventral parapodial papilla; vc, ventral cirrus.

\section{Results}

Family Sphaerodoridae Malmgren, 1867

Genus Sphaerodorum Örsted, 1843

\section{Sphaerodorum gracile (Rahtke, 1843)}

Ephesia gracilis Rathke, 1843. Nova Acta Acad. Caesareae Leopold.-Carol. Ger. Nat. Curiosor, 20(1): 176

Sphaerodorum flavum Örsted, 1843. Annulator. Danicor. Conspec., 1: 43 
Bebryce peripatus Johnston in Thompson, 1844. Rep. Br. Assoc. Adv. Sci., [1843], 13: 273

Pollicita peripatus (Johnston in Thompson): Johnston, 1845. Ann. Mag. Nat. Hist., 16: 4

Sphaerodorum peripatus (Johnston in Thompson): Grube, 1850. Arch. Naturgesch., 16(1): 315

Hypephesia gracilis (Rathke): Perrier, 1897. Traité Zool., 2(4): 1625

Sphaerodorum gracilis (Rathke): Lützen, 1961. Cah. Biol. Mar., 2: 414

Material EXAmined. DIVA-Artabria I 2003. EBS-600, 5 specimens; DRN-600, 4 spec. (MNCN 16.01/13265). Vertidos 2004. GA-EBS-600, one spec. DIVA-Artabria II 2009. EBS94, 2 spec.

Distribution AND ECOlOGY. Cosmopolitan, from eastern Atlantic and Mediterranean Sea to Arctic latitudes, South Africa and Japan (Day, 1967; Imajima, 1969; Fauchald, 1974; Parapar et al., 1996; Kirkegaard, 2001). Records from out of European waters might actually refer to other taxa (Fauchald, 1974). Hard and soft bottoms, 0-1500 m.

Genus Ephesiella Chamberlin, 1919

\section{Ephesiella abyssorum (Hansen, 1878)}

Sphaerodorum peripatus Claparède, 1863. Beob. Anat. Entwickl. Wirbelloser Thiere Küste Normandie Angest.: 50 [non Sphaerodorum peripatus (Johnston in Thompson, 1844)] Sphaerodorum abyssorum Hansen, 1878. Nyt Mag. Naturvidensk., 24(3): 9

Ephesia peripatus (Claparède): Saint-Joseph, 1894. Ann. Sci. Nat., Zool., 7(17): 41 [non Sphaerodorum peripatus (Johnston in Thompson, 1844)]

Ephesiella peripatus (Claparède): Pettibone, 1963. Bull. - U.S. Natl. Mus., 227(1): 208 [non Sphaerodorum peripatus (Johnston in Thompson, 1844)]

Ephesiella abyssorum (Hansen): Hartman \& Fauchald, 1971. Allan Hancock Monogr. Mar. Biol., 6: 65

Material EXAMINED. DIVA-Artabria II 2009. EBS-96, one specimen (MNCN 16.01/13266).

DistRIBUTION AND ECOLOGY. Eastern Atlantic and Mediterranean Sea (Desbruyères et al., 1972; Fauchald, 1974; Gil \& Sardá, 1999). Hard and soft bottoms, $0-150 \mathrm{~m}$.

Genus Sphaerodoridium Lützen, 1961

Sphaerodoridium fauchaldi Hartmann-Schröder, 1993

Sphaerodoridium fauchaldi Hartmann-Schröder, 1993. Mitt. Hamb. Zool. Mus. Inst., 90: 123

Material examined. DIVA-Artabria I 2003. EBS-100, 14 specimens (MNCN 16.01/13267); EBS-150, 52 spec.; EBS-
200, 2 spec. Vertidos 2004. GA-EBS-150, 3 spec.; GA-EBS200, one spec.; CA-EBS-150, 19 spec.; AG-EBS-150, 42 spec.; AG-EBS-250, 6 spec. DIVA-Artabria II 2009. EBS-93, one spec.; EBS-94, 41 spec.; EBS-95, 27 spec.

Distribution AND ECOlOGY. North Sea (Hartmann-Schröder, 1993), Capbreton Canyon, Bay of Biscay (Aguirrezabalaga \& Ceberio 2005), Ártabro Gulf (Moreira \& Parapar, 2007). Examination of samples collected during the expeditions reported here indicates that this species is frequent in sandy-muddy sediments along the Galician western continental shelf, from the Ártabro Gulf in the north to off the Ría de Vigo in the South, at depths of $102-495 \mathrm{~m}$.

\section{Genus Sphaerodoropsis Hartman \& Fauchald, 1971}

Sphaerodoropsis sibuetae Desbruyères, 1980 (Fig. 1)

Sphaerodoropsis sibuetae Desbruyères, 1980. Bull. Mus. natn. Hist. nat., Paris, $4^{e}$ ser., 2, sect. A(1): 226

Material eXAmined. DIVA-Artabria II 2008. DRN-30, one specimen (MNCN 16.01/13268).

DESCRIPTION. One complete specimen $4.0 \mathrm{~mm}$ long, $0.9 \mathrm{~mm}$ wide excluding parapodia, with 24 chaetigers. Body short, grub-like, lacking pigmentation, transparent-whitish in ethanol. Prostomium bluntly rounded, fused to peristomium. Median antenna and 3 pairs of lateral prostomial appendages (Fig. 1A, B). Median antenna digitiform. Dorsal antenniform papillae slender, shorter than median antenna. Intermediate antennae and palps digitiform, longer than median antenna. One pair of peristomial cirri, similar in size and shape to intermediate antennae and palps. About 20 digitiform papillae encircled by lateral prostomial appendages; a similar number of digitiform papillae surrounding mouth opening ventrally. Eyes not observed. Pharynx visible by transparency; muscular proventricule cylindrical, extending over 7 chaetigers.

Dorsal macrotubercles sessile, spherical to pearshaped. Two macrotubercles on chaetiger 1; from chaetiger 2 backwards four macrotubercles on each chaetiger in a transverse row. Dorsal body surface covered with rounded papillae arranged in four irregular transversal rows per chaetiger. Ventral body surface covered with papillae similar to those on dorsal surfaces, arranged in about five irregular transversal rows per chaetiger.

Parapodia uniramous, with wrinkled surface, about twice as long as wide (Fig. 1C-E). Digitiform 


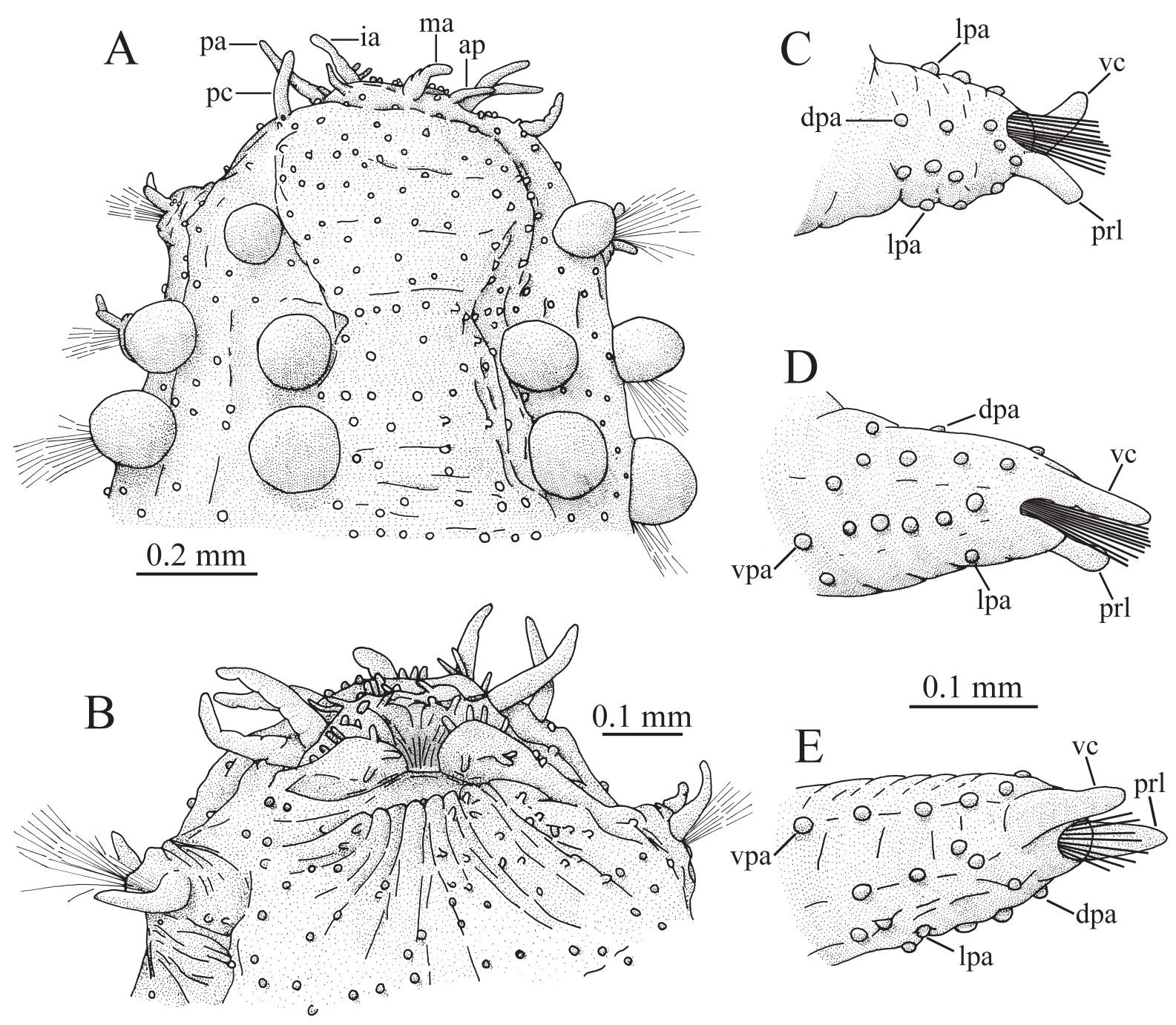

Fig. 1.- Sphaerodoropsis sibuetae. Dorsal (A) and ventral (B) view of anterior end. Dorsal (C) and ventral (E) view of middle parapodium. Lateroventral view of middle parapodium (D).

Fig. 1.- Sphaerodoropsis sibuetae. Vista dorsal (A) y ventral (B) del extremo anterior. Vista dorsal (C) y ventral (E) de un parápodo medio. Vista lateroventral de un parápodo medio (D).

prechaetal lobe from chaetiger one backwards, projecting beyond acicular lobe; postchaetal lobe absent. Ventral cirri digitiform, about as long as prechaetal lobe, surpassing acicular lobe tip. Parapodia with up to 25-27 rounded papillae, more or less arranged in longitudinal rows: 8 papillae on dorsal surface, three of them right behind prechaetal lobe, 3-4 on each lateral surface and 911 on ventral and ventrolateral surfaces. One thick, straight acicula per parapodium. Composite chaetae numbering 20-25 per parapodium. Blades unidentate, long, with cutting margin apparently smooth under optical microscope; blades in each fascicle showing gradation in length $(64-37 \mu \mathrm{m})$.

Pygidium contracted; anal cirri not seen.

REMARKS. The specimen collected in the Galician Continental Margin agrees well with the original description by Desbruyères (1980), mostly regarding the number and arrangement of the parapodial papillae. In fact, the number of parapodial papillae of $S$. 
sibuetae is much higher than that of the other eastern Atlantic species of Sphaerodoropsis provided with four dorsal macrotubercles per segment, namely $S$. parva (Ehlers, 1913) sensu Desbruyères, 1980, $S$. laureci Desbruyères, 1980, S. longipapillata Desbruyères, 1980, S. martinae Desbruyères, 1980, S. stellifer Aguirrezabalaga \& Ceberio, 2005 and $S$. artabrensis Moreira \& Parapar, 2007. In addition, $S$. laureci and $S$. martinae differ from the aforementioned species in the particular shape of their macrotubercles; S. stellifer has body papillae which are star-shaped distally instead of rounded; the parapodia of $S$. longipapillata bear one long, erect papilla just behind the prechaetal lobe. On the other hand, the presence of $S$. parva in the north-east Atlantic should be reviewed (Desbruyères, 1980; Reuscher \& Fiege, 2011). This species was originally described from Antarctica and later reported from other localities in the Southern Ocean. However, descriptions of this species differ in the number and arrangement of parapodial papillae (e.g. Fauchald, 1974; Desbruyères, 1980; Hartmann-Schröder \& Rosenfeldt, 1988) which suggests that perhaps those records might actually refer to several similar species.

Distribution AND ECOlOgY. Banc Le Danois, Bay of Biscay (Desbruyères, 1980), continental slope off Galicia (NW Iberian Peninsula) (this work). Muddy sediments, 1913-2034 m. This record extends the known distribution of $S$. sibuetae to the West.

Sphaerodoropsis amoureuxi Aguirrezabalaga \& Ceberio, 2005 (Fig. 2)

Sphaerodoropsis amoureuxi Aguirrezabalaga \& Ceberio, 2005. Cah. Biol. Mar., 46(1): 10

Material eXAmined. DIVA-Artabria I 2003. EBS-100, one specimen. Vertidos 2004. GA-EBS-200, one spec. (MNCN 16.01/13269). DIVA-Artabria II 2009. EBS-94, one spec.

DESCRIPTION. Three complete specimens, measuring 1.1.-3.5 mm long, 0.2-0.5 mm wide (excluding parapodia), with 17-22 chaetigers. Prostomium anteriorly rounded, somewhat contracted in specimens examined (Fig. 2A-B). Eyes not observed. Median antenna short, distally rounded. Dorsal antenniform papillae not distinguished, probably contracted. One pair of intermediate antennae and one pair of palps, digitiform, longer than median antenna, provided with papillar spurs (palps with 45 spurs; intermediate antennae with up to 6). Several papillae encircled by lateral paired prosto- mial appendages. Peristomial cirri digitiform, enlarged at base, with 4-5 papillar spurs; about 4-6 papillae dorsally to peristomial cirri, digitiform or apparently contracted.

Dorsal macrotubercles sessile, spherical, arranged in one transverse row per chaetiger; 6 macrotubercles in chaetiger 1, 7 macrotubercles in chaetiger 2, 8 macrotubercles from chaetiger 3 backwards. Spherical papillae among rows of macrotubercles, arranged in 2-3 transversal rows per chaetiger, irregularly distributed, numbering up to 9-10 per row. Ventral surface with spherical papillae arranged in 3-4 transversal rows per chaetiger, numbering up to 5-7 per row (Fig. 2E).

Parapodia uniramous (Fig. 2C-D); acicular lobe distally rounded to more or less triangular. Ventral cirrus conical, extending well beyond acicular lobe. One postchaetal lobe from chaetiger 1; an additional prechaetal lobe from chaetiger 3; chaetal lobes digitiform. Two parapodial papillae, one on ventral face and one on lateroanterior face. About 6-8 composite chaetae per parapodia; blades unidentate, cutting margin smooth, showing dorsoventral gradation in length $(20-14 \mu \mathrm{m})$.

Pygidium with two distal macrotubercles, long anal cirrus with two digitiform papillae (Fig. 2F).

REMARKS. The examined specimens correspond well to the original description of the species, mostly regarding appearance of lateral prostomial appendages and parapodia, and number and distribution of dorsal macrotubercles and papillae. The only minor differences among specimens from the NW Iberian Peninsula and those of the type series were the possession of one postchaetal lobe instead of 1-2 and 2 parapodial papillae instead of 2-4, respectively. In addition, the dorsal antenniform papillae and a third pygidial papilla were not clearly distinguished in Galician specimens; this could, however, be due to state of contraction of the examined specimens. The only species of the genus previously reported from the area which is provided with more than 4 macrotubercles per segment arranged in a single transversal row is Sphaerodoropsis minuta (Webster \& Benedict, 1887). This species may easily be distinguished from $S$. amoureuxi by bearing between 10-14 macrotubercles per segment.

Distribution And ecology. Capbreton Canyon, Bay of Biscay (Aguirrezabalaga \& Ceberio, 2005), Galician western continental shelf (this work). Soft bottoms, 102-1029 $\mathrm{m}$. This record extends its known distribution to the West. 


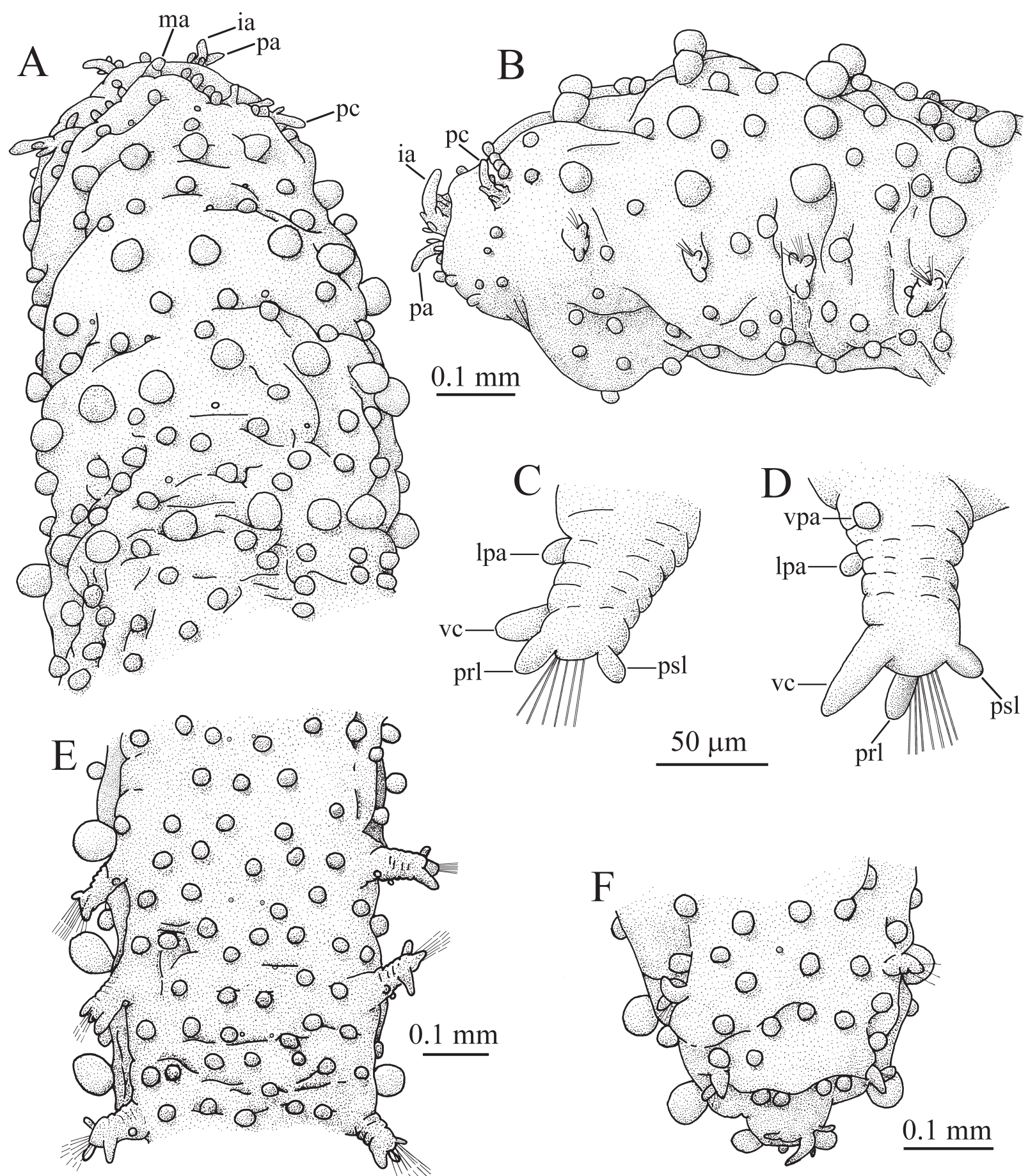

Fig. 2.- Sphaerodoropsis amoureuxi. Dorsal (A) and lateral (B) view of anterior end. Dorsal (C) and ventral (D) view of middle parapodium. Ventral view of mid-body chaetigers (E). Ventral view of distal end (F). A-B, C-D, same scale bar.

Fig. 2.- Sphaerodoropsis amoureuxi. Vista dorsal (A) y lateral (B) del extremo anterior. Vista dorsal (C) y ventral (D) de un parápodo medio. Vista ventral de setígeros de la parte media del cuerpo (E). Vista ventral del extremo posterior (F). A-B, C-D, misma escala. 


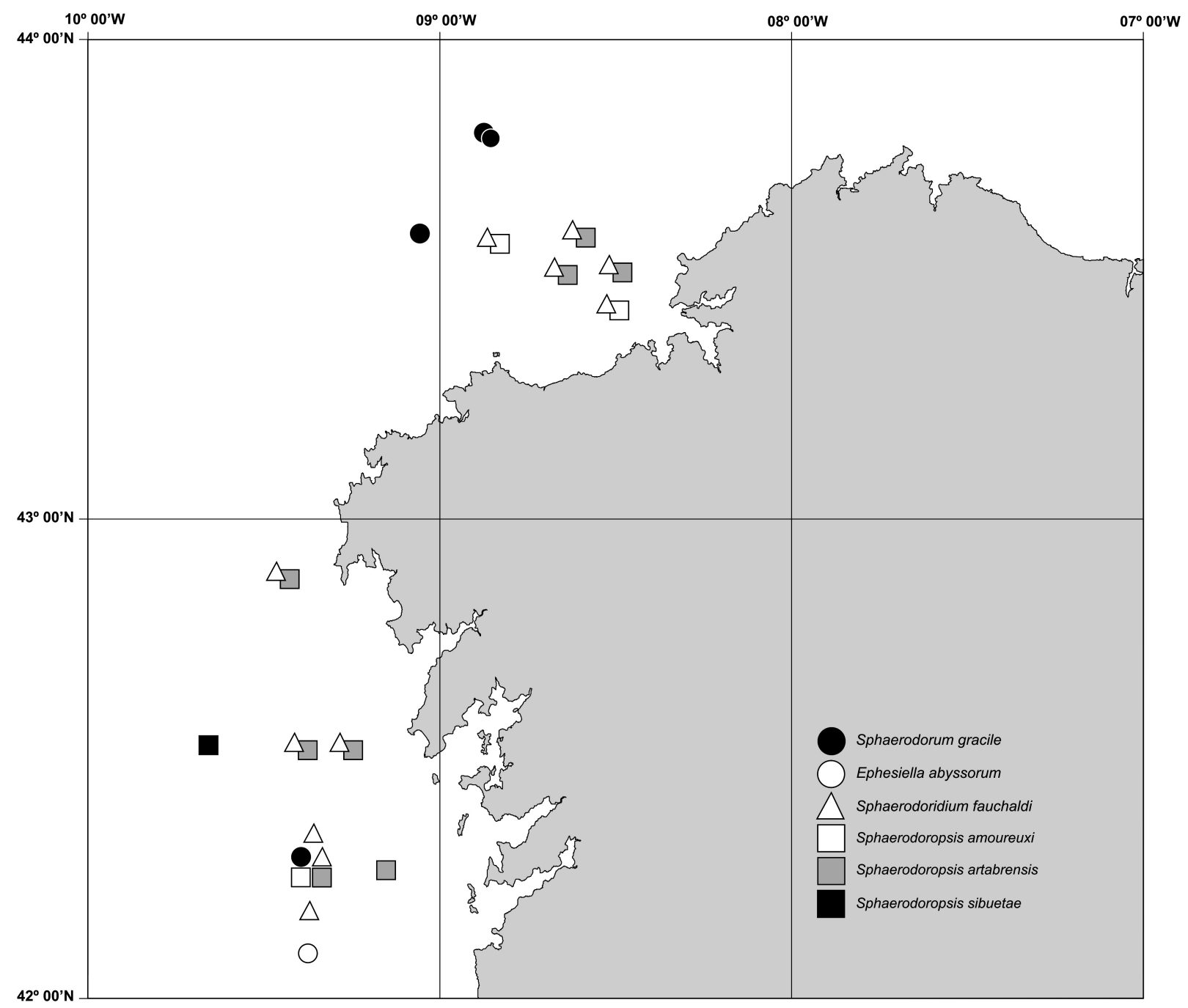

Fig. 3.- Distribution of Sphaerodoridae species from DIVA-Artabria / 2003, Vertidos 2004, DIVA-Artabria // 2008 and 2009 expeditions along Galician Continental Margin.

Fig. 3.- Distribución de las especies de Sphaerodoridae de las expediciones DIVA-Artabria / 2003, Vertidos 2004, DIVAArtabria // 2008 y 2009 a lo largo del Margen Continental de Galicia.

Sphaerodoropsis artabrensis Moreira \& Parapar, 2007

Sphaerodoropsis artabrensis Moreira \& Parapar, 2007. Cah. Biol. Mar., 48: 374

Material EXAmined. DIVA-Artabria 2003. EBS-150, 99 specimens; EBS-200, 40 spec. (MNCN 16.01/13270). Vertidos 2004. GA-EBS-150, 9 spec.; CA-EBS-150, 26 spec.; CH-EBS150, 6 spec.; AG-EBS-150, 79 spec.; AG-EBS-250, 2 spec. DIVA-Artabria II 2009. EBS-94, 12 spec.
DisTRIBUTION AND ECOLOGY. This recently described species shows a pattern of distribution similar to that of $S$. fauchaldi (see above); both species were frequently found co-occurring in the same samples (9 out of 14) and constituting 97\% of sphaerodorid specimens collected by means of the EBS. Sandy-muddy sediments, 148-264 m. 


\section{Discussion}

To date, 11 species of sphaerodorids have been found off the Iberian Peninsula, including those reported here: S. gracile, E. abyssorum, Sphaerodoridium claparedii (Greeff, 1866), S. fauchaldi, S. minuta, S. sibuetae, S. garciaalvarezi Moreira, Cacabelos \& Troncoso, 2004, S. amoureuxi, S. stellifer, $S$. artabrensis and Euritmia hamulisetosa Sardá, 1987. Of these species, S. gracile, E. abyssorum, S. claparedii and S. minuta are well distributed along European waters, from Arctic or Subarctic latitudes to the Mediterranean Sea; there are also records from other areas but some of those should be re-evaluated. For instance, reports of $S$. gracile from the southern Ocean turned out to actually refer to other, new taxa (Fauchald, 1974) and specimens initially identified as S. minuta from Alaska represented a new species (Kudenov, 1987a). In addition, $S$. gracile has been cited on a wide variety of substrata and at a range of depths, from the intertidal to the deep sea. It is also likely that records of these species from any given substratum or depth might refer to similar but different taxa, only distinguishable externally according to subtle characters which might have been overlooked in the past. In fact, recent work has shown that careful examination of shape and arrangement of parapodial and body papillae may constitute a reliable character to separate close species (see Kudenov, 1987b; Moreira et al., 2004; Reuscher \& Fiege, 2011). For example, the second described European species of Ephesiella, i.e. E. ramosae Desbruyères, 1980 from deep-sea areas of the Bay of Biscay, may be distinguished from E. abyssorum and other Ephesiella species according to the number and disposition of parapodial papillae.

Some sphaerodorid species seem to be restricted to a range of depths and/or substrata. For example, $S$. fauchaldi has only been found on soft bottoms at depths of between 100-500 m, in the North Sea, the Bay of Biscay and the Iberian Peninsula; Sphaerodoropsis artabrensis also shows a similar pattern of distribution (Fig. 3). On the other hand, $S$. stellifer and $S$. amoureuxi were originally described from soft bottoms at about $1000 \mathrm{~m}$ depth; the latter has also been found at the Galician continental shelf on soft bottoms but at shallower depths (102-264 m). Furthermore, the few known specimens of $S$. sibuetae were found at deeper bottoms than the aforementioned species (about $2000 \mathrm{~m}$ depth). Other species seem to be typical from subtidal areas, such as $S$. garciaalvarezi, which has been reported from soft bottoms not deeper than $30 \mathrm{~m}$ at the Galician rías (Moreira et al., 2004; Cacabelos et al., 2008). In the same way, E. hamulisetosa seems to be distributed from the Strait of Gibraltar to the northeastern Mediterranean coast of the Iberian Peninsula and has only been found at the intertidal zone and shallow subtidal (Martín, 1987; Sardá, 1987).

The sphaerodorid fauna from the soft bottoms of the Galician continental shelf (100-600 m depth) is dominated by $S$. fauchaldi and $S$. artabrensis; other species such as $S$. amoureuxi, $S$. gracile and $E$. abyssorum are less common and abundant at those depths and substrata, according to the results of sampling by means of the EBS. It can be expected that further sampling at deeper bottoms may reveal the presence of other deep-sea species previously reported from the Bay of Biscay, such as Clavodorum fauchaldi Desbruyères, 1980, E. ramosae, S. chardyi Desbruyères, 1980, S. laureci, $S$. longipapillata and $S$. martinae. In fact, $S$. chardyi has recently been reported from the southeastern Atlantic (Böggemann, 2009). Nevertheless, the actual distribution and ecological features of the aforementioned species cannot be properly assessed until more data are available from different substrata and depths. This will need an adequate processing of samples and the use of meshes finer than $1 \mathrm{~mm}$ due to the size of many of these polychaetes (Fauchald, 1974). Furthermore, an effective quantitative sampling in soft bottoms, whether they are in shallow or deep-sea areas, will also require the use of the appropriate sampling gear, such as the Epibenthic Sledge of Brenke (2005), as was demonstrated by Böggemann (2009) and Parapar \& Moreira (2009).

\section{Key to the Sphaerodoridae from the Iberian Penin- sula}

1. Macrotubercles with terminal papilla .............................. 2

- Macrotubercles lacking terminal papilla ........................... 3

2. All chaetae simple ...................... Sphaerodorum gracile

- Chaetae composite; simple hooks also present usually on chaetiger 1 Ephesiella abyssorum

3. Macrotubercles stalked .................................................... 4

- Macrotubercles sessile ......................................................... 5

4. Dorsal surfaces with macrotubercles and papillae ........ Sphaerodoridium claparedii - Dorsal surfaces with macrotubercles only Sphaerodoridium fauchaldi 
5. All chaetae composite

- All chaetae simple .

6. Macrotubercles arranged in one transversal row per chaetiger. 7

- Macrotubercles arranged in two transversal rows per chaetiger Sphaerodoropsis garciaalvarezi

7. $>4$ macrotubercles per chaetiger

- Four macrotubercles per chaetiger ... 8

8. Eight macrotubercles per chaetiger Sphaerodoropsis amoureuxi

- 10-14 macrotubercles per chaetiger Sphaerodoropsis minuta

9. 3-7 parapodial papillae 10

- >20 parapodial papillae .... Sphaerodoropsis sibuetae

10. Body papillae star-shaped ...... Sphaerodoropsis stellifer - Body papillae rounded .... Sphaerodoropsis artabrensis

\section{Acknowledgements}

The authors wish to thank Dr. V. Urgorri, the team leader of the DIVA-Artabria and Vertidos 2004 expeditions, for his support and help, the crews of the RVs Mytilus, Hespérides and Sarmiento de Gamboa and all researchers who participated in those expeditions for their help during work at sea. Special thanks to A. González, M. Pérez, G. Díaz-Agras, E. Gil, M. Candás, E. Corral, C. Varela and M. Zamarro (University of Santiago) for sorting most of the specimens and to J. Sánchez Almazán (MNCN, Madrid) for his help with deposit of voucher specimens. Constructive comments by M. Böggemann and one anonymous referee are greatly appreciated. This work was supported by the research projects DIVA-Artabria I (PGIDT 01PXI20008PR) of the Xunta de Galicia, DIVA-Artabria II (CTM2004-00740/MAR) and Fauna Ibérica IX: Annelida Polychaeta IV: Lumbrineridae, Oenonidae y Glyceriformia (CGL2007-66786-C08-02) of the Ministerio de Educación y Cultura, Spain.

\section{References}

Aguado, M. T. \& Rouse, G. W., 2006. First record of Sphaerodoridae (Phyllodocida: Annelida) from hydrothermal vents. Zootaxa, 1383: 1-21.

Aguirrezabalaga, F. \& Ceberio, A., 2005. Sphaerodoropsis amoureuxi and S. stellifer, two new species of Sphaerodoridae (Polychaeta) from the Capbreton Canyon (Bay of Biscay, NE Atlantic). Cahiers de Biologie Marine, 46: 9-20.

Böggemann, M., 2009. Polychaetes (Annelida) of the abyssal SE Atlantic. Organisms, Diversity and Evolution, 9: 251-428. doi:10.1016/j.ode.2009.10.001

Borowski, C., 1994. Three new deep-sea species of Sphaerodoridae (Annelida, Polychaeta) from the eastern tropical South Pacific. Zoologica Scripta, 23: 193-203. doi: 10.1111/j.1463-6409.1994.tb00384.x
Brenke, N., 2005. An epibenthic sledge for operations on marine soft bottom and bedrock. Marine Technology Society Journal, 39: 10-19. doi: 10.4031/002533205 787444015

Cacabelos, E., Moreira, J. \& Troncoso, J. S., 2008. Distribution of Polychaeta in soft-bottoms of a Galician Ria (NW Spain). Scientia Marina, 72: 655667. doi:10.3989/scimar.2008.72n4655

Campoy, A., 1982. Fauna de España. Fauna de Anélidos Poliquetos de la Península Ibérica. Ediciones de la Universidad de Navarra. Pamplona. 780 pp.

Day, J. H., 1967. A monograph on the Polychaeta of Southern Africa. British Museum (Natural History) Publication 656. London: 2 vols.: Pt 1, Errantia, 458 pp.; Pt 2, Sedentaria: 459-878.

Desbruyères, D., 1980. Sphaerodoridae (Annélides Polychètes) profonds du Nord-Est Atlantique. Bulletin du Muséum national d'Histoire naturelle, Paris, 4è sér., 2, Sect. A(1): 109-128.

Desbruyères, D., Guille, A. \& Ramos, J., 1972. Bionomie benthique du plateau continental de la côte catalane espagnole. Vie Milieu, 23 (2B): 335-363.

Fauchald, K., 1974. Sphaerodoridae (Polychaeta: Errantia) from world-wide areas. Journal of Natural History, 8: 257-289.

Gil, J. \& Sardá, R., 1999. New records of Annelida Polychaeta for the Portuguese fauna (with comments on some already known species). Arquivos do Museu Bocage, nova série, 3(10): 287-336.

Hartmann-Schröder, G., 1993. Sphaerodoridium fauchaldi sp. n., ein neuer Polychaet der Familie Sphaerodoridae aus der Nordsee (Polychaeta). Mitteilungen aus dem Hamburgischen Zoologischen Museum und Institut, 90: 123-125.

Hartmann-Schröder, G. \& Rosenfeldt, P., 1988. Die Polychaeten der "Polarstern"-Reise ANTIII/2 in die Antarktis 1984. Teil 1: Euphrosinidae bis Chaetopteridae. Mitteilungen aus dem Hamburgischen Zoologischen Museum und Institut, 85: 25-72.

Imajima, M., 1969. Three species of the family Sphaerodoridae (Polychaetous Annelids) from Japan. Bulletin of the Natural Science Museum, Tokyo, 12(1): 151-156.

Kirkegaard, J.B., 2001. Deep-sea polychaetes from northwest Africa, including a description of a new species of Neopolynoe (Polynoidae). Journal of the Marine Biological Association of the United Kingdom, 81: 391-397.

Kudenov, J. D., 1987a. Four species of Sphaerodoridae (Annelida: Polychaeta) including one new genus and three new species from Alaska. Proceedings of the Biological Society of Washington, 100: 917-926.

Kudenov, J. D., 1987b. Five new species of Sphaerodoridae (Annelida: Polychaeta) from the Gulf of Mexico. Proceedings of the Biological Society of Washington, 100: 927-935. 
Lützen, J., 1961. Sur une nouvelle espèce de polychète Sphaerodoridium commensalis n. gen., n. spec. (Polychaeta Errantia, famille des Sphaerodoridae) vivant en commensal de Terebellides stroemi Sars. Cahiers de Biologie Marine, 2: 409-416.

Martín, D., 1987. La comunidad de Anélidos Poliquetos de las concreciones de algas calcáreas del litoral catalán. Caracterización de las especies. Publicaciones del Departamento de Zoología de la Universidad de Barcelona, 13: 45-54.

Moreira, J., Cacabelos, E. \& Troncoso, J., 2004. A new species of Sphaerodoropsis (Polychaeta: Sphaerodoridae) from north-east Atlantic, with comments on other species of the genus. Journal of the Marine Biological Association of the United Kingdom, 84: 995-1000. doi: 10.1017/S002531540401029Xh

Moreira, J. \& Parapar, J., 2007. Sphaerodoridae (Annelida, Polychaeta) from the DIVA-ARTABRIA I project (2002 cruise) with description of a new species from the Ártabro Gulf (NW Iberian Peninsula). Cahiers de Biologie Marine, 48: 373-379.

Moreira, J. \& Parapar, J., 2011. Sphaerodoridae (Annelida: Polychaeta) from the Bellingshausen Sea (Antarctica) with the description of two new species. Polar Biology, 34: 193-204. doi: 10.1007/s00300-010-0869-X

Parapar, J., Besteiro, C. \& Urgorri, V., 1996. Inventario dos Poliquetos de Galicia (Annelida: Polychaeta). Cadernos da Area de Ciencias Biolóxicas. Publicación do Seminario de Estudos Galegos. 178 pp.

Parapar, J. \& Moreira, J., 2009. Polychaeta of the 'DIVA-Artabria I' project (cruise 2002) in the continental shelf and upper slope off Galicia (NW Spain). Cahiers de Biologie Marine, 50: 57-78.

Reuscher, M. \& Fiege, D., 2011. Sphaerodoridae (Annelida: Polychaeta) from the deep south-west Pacific, with the description of a new species of Sphaerodoropsis. Journal of the Marine Biological Association of the United Kingdom, 91: 439-445. doi: $10.1017 / \mathrm{S} 0025315410000469$
Sardá, R., 1983. Nuevas citas de anélidos poliquetos para la Península Ibérica. Publicaciones del Departamento de Zoología de la Universidad de Barcelona, 9: 1321.

Sardá, R., 1987. Sphaerodoridae (Annelida, Polychaeta) from the region of the Gibraltar Strait with description of Euritmia hamulisetosa gen. et sp. n. Zoologica Scripta, 16(1): 47-50.

Schüller, M. \& Ebbe, B., 2007. Global distributional patterns of selected deep-sea Polychaeta (Annelida) from the Southern Ocean. Deep Sea Research Part II: Topical Studies in Oceanography, 54: 1737-1751. doi:10.1016/j.dsr2.2007.07.005

Recibido / Received, 7-02-2011

Aceptado / Accepted, 14-04-2011 Publicado en línea / Published online, 27-04-2011 Publicado impreso / Published in print, 30-06-2011 